\title{
Extramedullary haematopoiesis resembling a blueberry muffin, in a neonate
}

\author{
Balaganesh Karmegaraj, Sowmya Vijayakumar, Ramanathan Ramanathan, \\ Ramesh Samikannu
}

Department of Pediatrics, Rajah Muthiah Medical College \& Hospital, Chidambaram, Tamil Nadu, India

\section{Correspondence to}

Dr Balaganesh Karmegaraj, kbgpho@gmail.com

Accepted 19 September 2015

\section{DESCRIPTION}

A $5 \mathrm{~h}$ old baby girl born prematurely presented with fever and rash all over the body since birth. Her mother had a history of fever without rash for 1 week during the second trimester. On physical examination, the baby had microcephaly, symmetrical intrauterine growth retardation, rash all over the body, palpable orbital swelling surrounded by ecchymosis (figure 1), jaundice and hepatosplenomegaly. The rash consisted of bluish-red, firm non-blanching macules and papules $0.5-1.0 \mathrm{~cm}$ in diameter over the face (figure 1) and entire body (figure 2).

Laboratory investigations revealed a haemoglobin level of $8.4 \mathrm{~g} / \mathrm{dL}$, white cell count of 44000 cells/ $\mathrm{mm}^{3}$ with lymphocytosis (86\%), platelet count of 34000 cells $/ \mathrm{mm}^{3}$ and conjugated hyperbilirubinemia (total bilirubin $17.5 \mathrm{mg} / \mathrm{dL}$, direct bilirubin $5.5 \mathrm{mg} / \mathrm{dL}$ ). A peripheral smear showed features of disseminated intravascular haemolysis and no

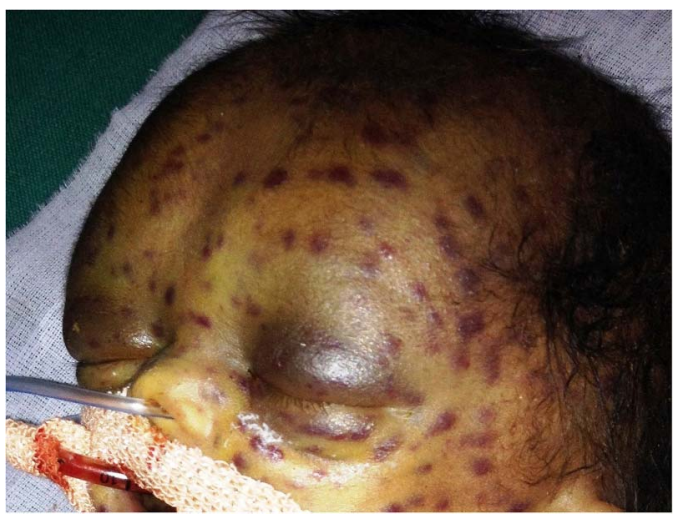

Figure 1 Orbital swelling surrounded by ecchymosis and bluish-red, firm non-blanching maculopapular rash over the face. evidence of blast cells. The baby's coagulation profile was deranged (prothrombin time $36 \mathrm{~s}$ (control 14), international normalised ratio (INR)

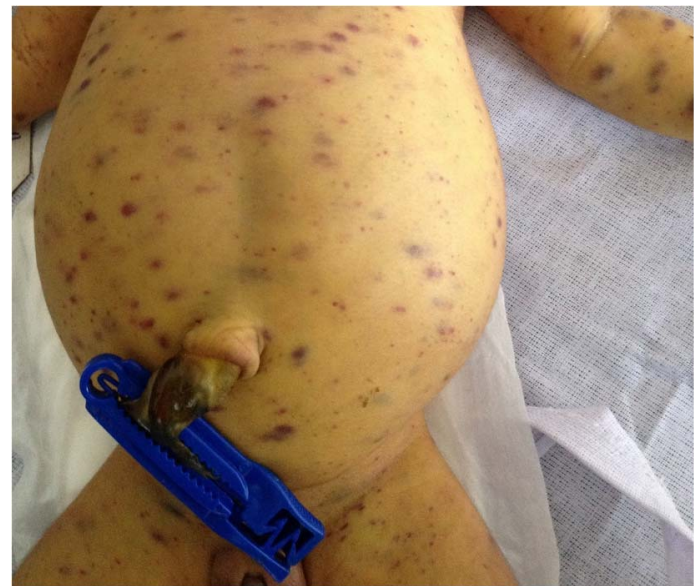

Figure 2 Bluish-red, firm non-blanching maculopapular rashes over the body.

\section{Learning points}

1. Detailed evaluation of a baby with blueberry muffin lesions is needed since it is an initial presenting feature of various aetiologies.

2. Extramedullary haematopoiesis should be differentiated from chloroma, which is usually isolated.

3. Chloromas presenting as periorbital swelling (raccoon eyes) are more commonly seen with neuroblastoma, and very infrequently in acute lymphoblastic lymphoma and acute myeloid leucaemia. ${ }^{3}$

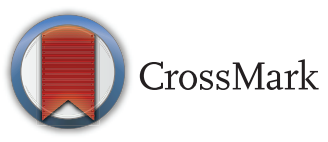

To cite: Karmegaraj $\mathrm{B}$ Vijayakumar $S$,

Ramanathan $\mathrm{R}$, et al. BMJ Case Rep Published online: [please include Day Month Year] doi:10.1136/bcr-2014208473
Table 1 Differential diagnosis for blueberry muffin lesions

\begin{tabular}{|c|c|}
\hline Infections & $\begin{array}{l}\text { (Congenital rubella infection, toxoplasmosis, herpes virus, parvovirus, coxsackievirus, Epstein-Barr virus, } \\
\text { syphilis) }{ }^{2}\end{array}$ \\
\hline Haematological & $\begin{array}{l}\text { Hereditary spherocytosis, fetomaternal transfusion, alloimmunisation, (Rh incompatibility, haemolysis due to } \\
\text { anti-Kp (a)), treatment with recombinant erythropoietin, transient neonatal myeloproliferative disorder }\end{array}$ \\
\hline Malignancies & Congenital leucaemia, Extraosseal Ewing sarcoma, alveolar rhabdomyosarcoma, neuroblastoma \\
\hline Systemic & Langerhans cell histiocytosis, Hashimato-Pritzker disease (congenital self-healing reticulohistiocytosis), lupus \\
\hline Vascular malformation & Haemangiomatosis \\
\hline Endocrine & Congenital transient neonatal hyperparathyroidism \\
\hline $\begin{array}{l}\text { Lysosomal storage } \\
\text { disorder }\end{array}$ & Mucolipidosis type II (I—cell disease) \\
\hline $\begin{array}{l}\text { Neurodevelopmental } \\
\text { disorder }\end{array}$ & Aicardi-Goutières syndrome \\
\hline
\end{tabular}


2.5, partial thromboplastin time $102.3 \mathrm{~s}$ (29.5-42.2)). Results of cytomegalovirus $\operatorname{IgM}(2.83 \mathrm{IU} / \mathrm{mL})$ and $\operatorname{IgG}(174 \mathrm{IU} / \mathrm{mL})$ tests were positive. Despite intensive treatment, the child did not survive.

Blueberry muffin lesion occurs due to dermal extramedullary haematopoiesis. ${ }^{1}$ The most common cause is congenital cytomegalovirus infection. Table 1 below shows the differential diagnosis of blueberry muffin lesions.

Contributors BK prepared the manuscript draft and managed the case. SV prepared the pictures. RR managed the case and reviewed the manuscript and reviewed the manuscript. RS reviewed the manuscript.
Competing interests None declared.

\section{Patient consent Obtained.}

Provenance and peer review Not commissioned; externally peer reviewed.

\section{REFERENCES}

1 Abdel-Latif Mel-A, Sugo E. Images in clinical medicine. Congenital cytomegalovirus infection. N Engl J Med 2010;362:833. http://dx.doi.org/10.1056/NEJMicm0804100

2 Bagna R, Bertino E, Rovelli I, et al. Benign transient blueberry muffin baby. Minerva Pediatr 2010;62:323-7.

3 Karmegaraj B, Latha MS, Manipriya R, et al. Periorbital chloroma mimicking raccoon eyes in a child with acute myeloid leukaemia. Arch Dis Child 2014;99:1025. http:/l dx.doi.org/10.1136/archdischild-2014-306149

Copyright 2015 BMJ Publishing Group. All rights reserved. For permission to reuse any of this content visit

http://group.bmj.com/group/rights-licensing/permissions.

BMJ Case Report Fellows may re-use this article for personal use and teaching without any further permission.

Become a Fellow of BMJ Case Reports today and you can:

- Submit as many cases as you like

- Enjoy fast sympathetic peer review and rapid publication of accepted articles

- Access all the published articles

- Re-use any of the published material for personal use and teaching without further permission

For information on Institutional Fellowships contact consortiasales@bmjgroup.com

Visit casereports.bmj.com for more articles like this and to become a Fellow 